\title{
THE EFFECTS OF SALT AND ALKALINE STRESS ON THE FOURWING SALTBUSH (ATRIPLEX CANESCENS (PURSH) NUTT.) STRESS
}

\author{
ZHANG, T.* - HE, K. N. - ZHANG, Z. Z. \\ College of Soil and Water Conservation, Beijing Forestry University, Beijing 100083, China \\ Key Laboratory of State Forestry Administration on Soil and Water Conservation, Beijing \\ Forestry University, Beijing 100083, China \\ *Corresponding author \\ e-mail:whitneylogan6017@gmail.com
}

(Received $8^{\text {th }}$ Mar 2019; accepted 21 ${ }^{\text {st }}$ May 2019)

\begin{abstract}
Atriplex canescens is a $\mathrm{C}_{4}$ fodder shrub that is excellent for phytore-mediation in saline-alkali environments. However, little is known about the response of this shrub species to salt and alkaline stress and its underlying physiological adaptive mechanisms. In this study, we treated 8-week-old A. canescens seedlings in the lab with neutral salt (NS) (1:1 molar ratio of $\mathrm{NaCl}$ to $\mathrm{Na}_{2} \mathrm{SO}_{4}, \mathrm{pH}$ 6.65-6.95) and alkali salt (AS) (1:1 molar ratio of $\mathrm{NaHCO}_{3}$ to $\left.\mathrm{Na}_{2} \mathrm{CO}_{3}, \mathrm{pH} 9.75-10.12\right)$ at five concentrations (0-400 mM). Our results showed that individual A. canescens seedlings could maintain growth under certain ranges of both NS stress and AS stress. These findings suggest that AS can more strongly inhibit A. canescens seedlings than can NS. This result was attributed to a decrease in photosynthetic ability and damage to $\mathrm{Na}^{+} / \mathrm{K}^{+}$ homeostasis under alkali salinity. Differences were evident in the NS and AS treatments for almost all of the considered parameters.
\end{abstract}

Keywords: adaptive mechanism, concentration, chlorophyll, photosynthesis, environmental science

\section{Introduction}

Primary and secondary soil salinization and alkalization are well-known constraints against the sustainable development of agriculture and land conservation, as they are critical environmental factors that can inhibit plant productivity (Flowers, 2004; Kalaji et al., 2016; Ogunyele et al., 2018). Natural salt-alkalinized soils are driven by various cations, such as $\mathrm{Na}^{+}, \mathrm{K}^{+}, \mathrm{Ca}^{2+}$ and $\mathrm{Mg}^{2+}$, and various anions, such as $\mathrm{Cl}^{-}, \mathrm{SO}_{4}{ }^{2-}, \mathrm{HCO}_{3}{ }^{-}$ and $\mathrm{CO}_{3}{ }^{2-}$ (Läuchli and Lüttge, 2002; Nwankwo and Nwankwoala, 2018). Based on salt characteristics, two types of stresses can be incurred from salt-alkalinized soils. Neutral salt (NS) stress, which is induced by a high amount of $\mathrm{NS}$ such as $\mathrm{NaCl}$ and $\mathrm{Na}_{2} \mathrm{SO}_{4}$. And alkali salt (AS) stress, which is caused by $\mathrm{NaHCO}_{3}$ and $\mathrm{Na}_{2} \mathrm{CO}_{3}$ (Shi and Yin, 1993; Jamil et al., 2018). AS stress can impact plants more severely than deleted NS stress (Shi and Yin, 1993; Gong et al., 2014; Nkwuda et al., 2019). Furthermore, plants growing in salt-alkalinized soils are affected by both NS and AS.

Salinity can exert osmotic and toxic effects on plants, consequently damaging the photosynthetic process and impeding plant growth (Benzart Maali et al., 2012; Kumar, 2018). High-salt environments can disrupt ionic homeostasis in plant tissues. The reestablishment of both ionic balance and osmotic adjustment is a key functional mechanism for plant survival under NS stress (Li et al., 2003; Tianlei, 2019). Compared to that of NS stress, the higher $\mathrm{pH}$ value of AS stress can impose greater effects on plants, probably because the alkalinity of saline soils can severely disrupt both ionic and pH homeostases in plant tissues (Yang et al., 2008; Rajendran and Mohsin, 2018). 
Therefore, plants under AS stress may suffer not only from ion toxicity and physiological drought but also from alkaline stress in high-pH environments. To resist AS stress, plants must allocate higher amounts of energy to regulate the $\mathrm{pH}$ in their roots to maintain intracellular ionic balance (Yang et al., 2007; Sufiyan et al., 2018).

Due to the high adaptability of halophytes to saline and alkaline environments, many studies have examined the physiological responses of these types of plants to salt stress (Maali Benzart et al., 2014). Many studies have found that moderate salt solutions can stimulate net photosynthetic rates (Pns) (i.e., the highest rates of net photosynthesis ar found in plants under moderate salt concentrations). For example, the growth rate of the $\mathrm{C}_{3}$ perennial halophyte shrub Atriplex portulacoides peaked at $200 \mathrm{mM} \mathrm{NaCl}$ concentrations (Redondo-Gómez et al., 2007; Madhav et al., 2018). Halophytes can survive in saline environments by employing the following mechanisms: enhancing photosynthetic ability, reducing $\mathrm{Na}^{+}$concentrations in the cytosol and using $\mathrm{Na}^{+}$as an osmoregulator to maintain cellular ion homeostasis, as well as improving water status via osmotic adjustment by producing compatible solutes (Shabala et al., 2014; Flowers et al., 2015). For instance, Puccinellia tenuiflora can limit $\mathrm{Na}^{+}$influx to maintain a high $\mathrm{K}^{+} / \mathrm{Na}^{+}$ratio in the shoots (Niu et al., 2016; Raj and Prabhakaran, 2018). However, studies on the effects of salt stress on plants have mainly focused on NS environments dominated by $\mathrm{NaCl}$. Few studies have investigated the impact of alkaline stress on halophytes and their underlying mechanisms, which may have implications for better utilization and restoration of salt-alkalinized soil.

Furthermore, recent studies have typically used herbs and crops, including Chloris virgate, $P$. tenuiflora, Kochia sieversiana, wheat, oats and tomato, to investigate the effects of salt and alkaline stress on plants (Yang et al., 2008). However, how halophytes are affected by salt and alkaline stress and the way they physiologically respond in saline and alkaline environments are not well understood. The saline-alkali region in Northwest China also experiences long periods of drought, gale-force winds and dust. Therefore, shrubs have great implications in land restoration and local economies, as shrubs cannot be replaced by herbs and crops due to the lack of ecological functions, such as disrupting wind and preventing erosion, of those two plant types. The $\mathrm{C}_{4}$ perennial evergreen shrub Atriplex canescens, which belongs to the Chenopodiaceae family, is native to xeric and saline deserts in North America. Due to its strong resistance to drought (annual rainfall of 90-350 mm), salinity (soil salinity of 0.5-1.5\%, and cold (elevation of 500-3500 m) (Glenn and Brown, 1999; Kong, 2013), this species is well naturalized and adapted to a wide range of environments. It is widely used as fodder and screens and for preventing soil erosion and soil recovery (Peterson et al., 1987; Benzarti et al., 2013). This shrub species was introduced to China in 1990 and has shown the ability to maintain high levels of photosynthesis and growth rates throughout a wide range of $\mathrm{NaCl}$ concentrations (Pan et al., 2016). Therefore, $A$. canescens represents an excellent phytoremediation plant in saline-alkali environments (Benzarti et al., 2013). However, it is not clear whether the photosynthesis and growth of $A$. canescens differ between AS and NS environments. In this study, we conducted a controlled experiment by simulating neutral and alkali soil salt conditions along a concentration gradient from 0 to $400 \mathrm{mM}$ in order to compare the different effects of NS and AS on the growth and physiological response of A. canescens. To understand the different impact of salt and alkaline stress on their plants and their physiological response traits, we tested the following three hypotheses:

1. AS more strongly inhibits plant growth than does NS. 
2. AS more strongly inhibits plant photosynthetic ability than does NS.

3. The $\mathrm{Na}^{+}$and $\mathrm{K}^{+}$contents in A. canescens seedlings are more strongly influenced by AS than by NS.

\section{Materials and methods}

\section{Experimental treatments}

\section{Plant materials}

We collected seeds of A. canescens from the Academy of Agriculture and Forestry Sciences, Qinghai University, China. The seeds were treated with $\mathrm{H}_{2} \mathrm{SO}_{4}$ and distilled water and then were germinated in washed sand under dark conditions for 8 days in a greenhouse. A total of 100 plastic pots were used to house the germinated A. canescens seeds; the size of each pot was $10 \mathrm{~cm} \times 10 \mathrm{~cm} \times 10 \mathrm{~cm}$. Each pot was filled with $1 \mathrm{~kg}$ of washed soil $\left(1.36 \mathrm{~g} / \mathrm{cm}^{3}\right.$ of soil bulk density) and contained 2 seedlings. The seedlings were watered with 1/2-strength Hoagland nutrient solution at 2-day intervals until a suitable soil moisture content $(19.96 \pm 1.32 \%, 79.64 \%$ percentage of field capacity) was reached. We examined the relationship between the diurnal variation in soil water and seedling growth and defined the suitable soil moisture content as that at which the highest plant growth rates occurred. The climatic conditions of the greenhouse included a temperature of $27.5 \pm 1.5{ }^{\circ} \mathrm{C} / 19.0 \pm 1.5{ }^{\circ} \mathrm{C}$ (day/night) and a photoperiod of $16 \mathrm{~h} / 8 \mathrm{~h}$ (light/dark). We controlled the photosynthetically active radiation (PAR) to be $800 \mu \mathrm{mol} \mathrm{m} \mathrm{m}^{-2} \mathrm{~s}^{-1}$ and the relative humidity to be $60 \pm 2.5 \%$.

\section{Design of simulated salt and alkali conditions}

The northwestern inland saline-alkali area in China is characterized by a low annual precipitation $(43.5 \mathrm{~mm})$ and a very high intensity of solar radiation $\left(2940 \mathrm{KJ} \mathrm{cm}^{-2}\right)$. The soil salts are mainly composed of $\mathrm{NaCl}, \mathrm{Na}_{2} \mathrm{SO}_{4}, \mathrm{NaHCO}_{3}$ and $\mathrm{Na}_{2} \mathrm{CO}_{3}$. Accordingly, we simulated the $\mathrm{NS}$ conditions by mixing $\mathrm{NaCl}$ and $\mathrm{Na}_{2} \mathrm{SO}_{4}$ at a molar ratio of 1:1. To simulate the AS conditions, we mixed $\mathrm{NaHCO}_{3}$ and $\mathrm{Na}_{2} \mathrm{CO}_{3}$ at a molar ratio of 1:1. Under each salt condition, five levels of soil solution salt concentrations were applied: 80, 160, 240, 320, and $400 \mathrm{mmol} \mathrm{L}^{-1}(\mathrm{mM})$.

\section{Stress treatment}

A total of 72 uniform 8-week-old seedlings (36 pots) were selected and randomly divided into 12 sets. Each set consisted of 3 pots, and each pot contained two plants. One set was used to measure the initial size of the seedlings at the beginning of the treatment, and one set was used as a control group during the whole treatment. Five sets were used for AS stress treatments, while the other five sets were used for NS stress treatments.

By using the soil solution's salt concentrations, soil bulk density and soil moisture content data, we calculated the quantity of the four different salts added to each treatment. One fifth of the salt quantity were added to the plants along with $200 \mathrm{~mL} \mathrm{1/2}$ strength Hoagland nutrient solution between 17:30 and 18:30 every day for five days until the salt quantity reached the desired level. After the desired salt concentrations in the soil were met, the treatments continued for 20 days in the greenhouse. And the soil 
moisture contents in all pots were kept constant at $19.96 \pm 1.32 \%$ throughout the whole experiment.

\section{Measurement of parameters}

Growth

Shoot and root relative growth rates (RGRs) were measured. After the experiment, we harvested the whole plants, separated the shoots from the roots and then dried the tissue at $80{ }^{\circ} \mathrm{C}$ for $48 \mathrm{~h}$. We calculated the RGR of both the shoots and roots in accordance with the methods of Kingsbury et al. (1984) as follows: RGR $=\left(\ln D_{1}-\ln \right.$ $\left.\mathrm{DM}_{0}\right) / \mathrm{D}$, where $\mathrm{DM}_{1}$ denotes the dry mass at the end of the stress treatment, $\mathrm{DM}_{0}$ refers to the initial dry mass at the beginning of the stress treatment, and DM is the total treatment duration in days.

\section{Photosynthesis}

To measure the photosynthetic ability of the plants, the Pn, stomatal conductance (Gs), transpiration rate (Tr) and chlorophyll (chl) content were measured. Before harvesting the plants, we selected a total of three fully expanded leaves on the upper, middle and lower parts of the seedlings for measuring their Pn, Gs and Tr under a light intensity of $1000 \mu \mathrm{mol} \mathrm{m} \mathrm{m}^{-2} \mathrm{~s}^{-1}$ by using an Li-6400 portable photosynthesis system (LiCor, Lincoln, NE, USA) between 10:00 and 11:00. For each leaf, three replicate measurements were performed for each parameter. The same leaves used for measuring Pn were used for measuring leaf area and chl content. We used a photo scanner (CS4200F; Canon, Inc., Tokyo, Japan) to estimate the leaf area. The water use efficiency (WUE) was calculated as the $\mathrm{Pn} / \mathrm{Tr}$ ratio. The chl a (Chla), chl b (Chlb) and carotenoids (Car) were extracted by using acetone, and their contents were determined with a spectrophotometer (UV-6100PCS; Mapada Instruments, Co., Ltd., Shanghai, China) at 440-, 654-, and 663-nm wavelengths, respectively. Their concentrations were calculated in accordance with the equations (Lichtenthaler, 1987).

\section{$\mathrm{Na}^{+}, \mathrm{K}^{+}$concentrations}

The roots, stems and leaves were carefully separated and rinsed with deionized water, after which they were dried in an oven at $80{ }^{\circ} \mathrm{C}$ for $72 \mathrm{~h}$. The $\mathrm{Na}^{+}$and $\mathrm{K}^{+}$ions were extracted from the dried tissues by using $100 \mathrm{mM}$ acetic acid at $90{ }^{\circ} \mathrm{C}$ for at least $2 \mathrm{~h}$. The extractions were then transferred to a water bath, cooled and filtered, after which the cation accumulation was determined by using a flame spectrophotometer (Model 410 Flame; Sherwood Scientific, Ltd., Cambridge, UK) (Bao et al., 2016). Three replicates were used per measurement.

\section{Statistical analysis}

One-way analysis of variance (ANOVA) was performed for each measurement by using SPSS statistical software (Ver. 19.0, SPSS, Inc., Chicago, IL, USA). Duncan's multiple range test (DMRT) was used to identify significant differences among the means at a significance level of $\mathrm{P}<0.05$. All the acquired data were presented as the average values and their standard errors (SEs). 


\section{Results}

In total, 66 seedlings ( 1 set of control treatment, 5 sets of NS treatment and 5 sets of AS treatment) were analysed. The mean height of the A. canescens seedlings was $12.26 \pm 1.90 \mathrm{~cm}$ and $10.43 \pm 1.21 \mathrm{~cm}$ under NS and AS conditions $(0-400 \mathrm{mM})$, respectively, after 20 days.

\section{Effects of NS and AS on the growth of A. canescens seedlings}

The growth of $A$. canescens seedlings under the AS treatment differed from that under the NS treatment at the same level of salinity (Fig. 1). A moderate NS concentration (i.e., $160 \mathrm{mM}$ ) caused a growth peak for both the shoots and roots. When the NS concentration reached $240 \mathrm{mM}$ or greater $(<400 \mathrm{mM})$, the shoot growth rates did not significantly differ from those under the non-saline conditions. Under AS conditions, the peak growth of the both the shoots and roots occurred at the lowest AS concentration $(80 \mathrm{mM})$. Further increases in the AS concentrations considerably reduced the growth rates, especially for the root RGR above the AS concentration of $240 \mathrm{mM}$, which had already significantly inhibited root growth.

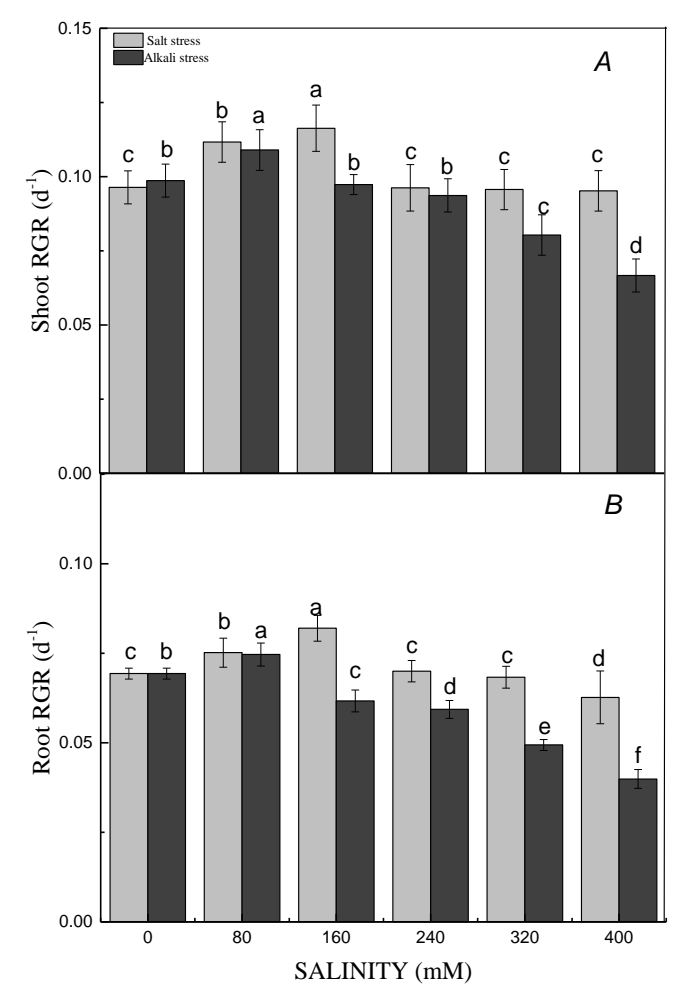

Figure 1. The mean relative growth rates $(R G R s)$ of the shoots $(A)$ and roots $(B)$ of $A$. canescens seedlings under different neutral salt (NS) and alkali salt (AS) concentrations (0-400 $m M)$ after 20 days. The error bars indicate the $95 \%$ confidence intervals of the means. Different letters in the same panel indicate significant differences at $P<0.05$ according to the Duncan test

\section{Effects of NS and AS on photosynthetic ability of A. canescens seedlings}

The variation in leaf Pn as salinity increased under AS conditions differed from that under NS conditions (Fig. 2). The Pn significantly and continuously increased as 
salinity increased under NS conditions. Moderate AS concentrations increased the Pn; however, compared with that of the control, the Pn decreased dramatically when the AS concentration reached $320 \mathrm{mM}$ or above. NS concentrations of $160 \mathrm{mM}$ and AS concentrations of $80 \mathrm{mM}$ resulted in highest leaf Gs values. The leaf Gs gradually decreased as salinity further increased. However, A. canescens seedlings subjected to NS and AS conditions presented different leaf Ci contents. When exposed to NS, the Ci continuously decreased as the salt concentration increased in NS treatment, and similar trend was observed under AS conditions. Furthermore, under AS conditions, after reaching the lowest content at $240 \mathrm{mM}$, the $\mathrm{Ci}$ sharply increased at $320 \mathrm{mM}$. Correspondingly, leaf WUE was significantly reduced at $160 \mathrm{mM}$ but gradually increased as the salinity concentration increased. At salinity concentrations of $320 \mathrm{mM}$, the leaf WUE was higher under NS conditions than under AS conditions.

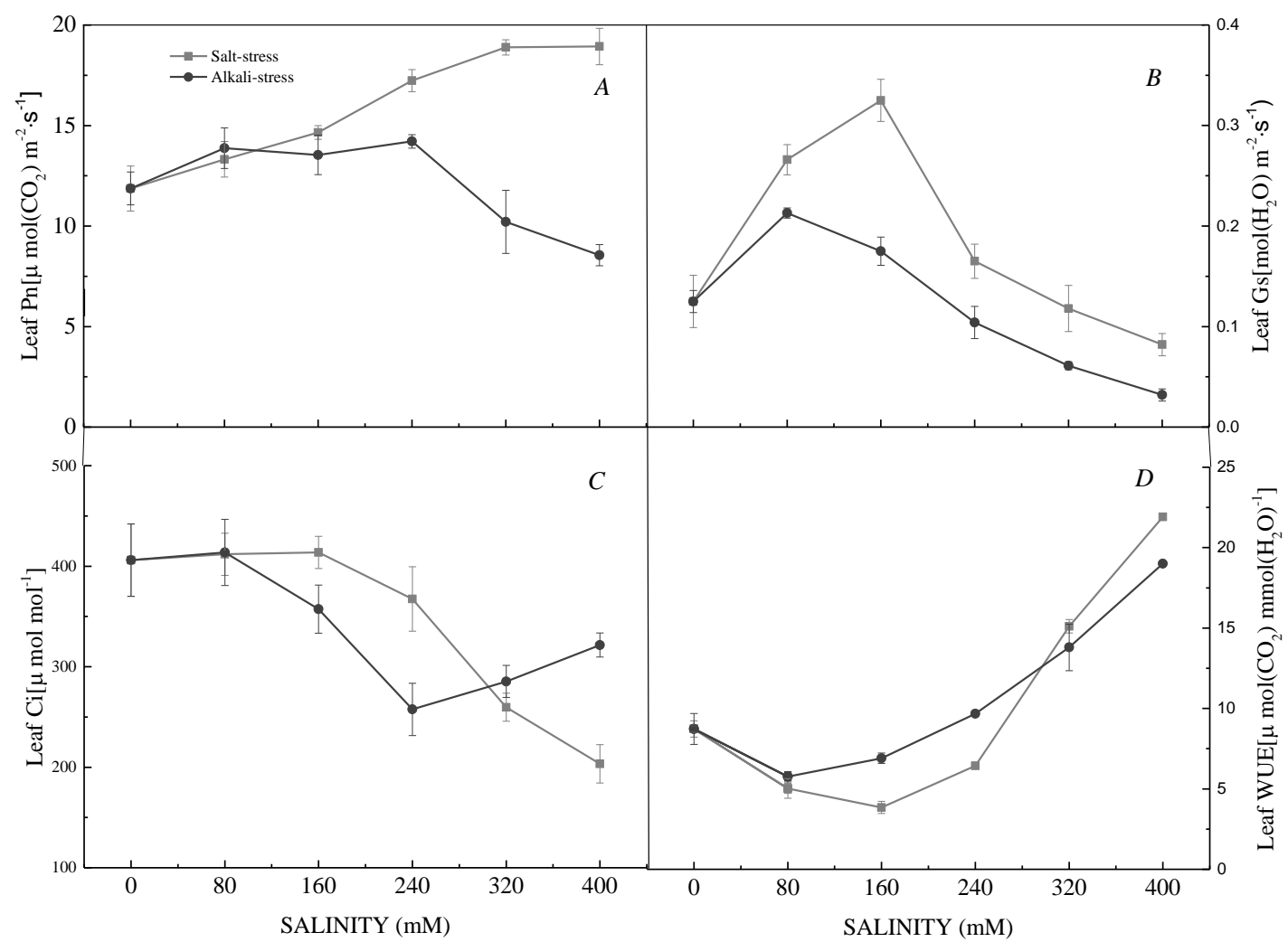

Figure 2. Mean leaf net photosynthetic rate (Pn) (A), leaf stomatal conductance (Gs) (B), leaf intercellular $\mathrm{CO}_{2}$ concentration $(\mathrm{Ci})(\mathrm{C})$, and leaf water use efficiency (WUE) (D) of $A$. canescens seedlings under different NS and AS concentrations (0-400 mM) after 20 days. The error bars indicate the $95 \%$ confidence intervals of the means

The leaf chl contents of the A. canescens seedlings under AS conditions were lower than those under NS conditions $(\mathrm{P}<0.05)$ (Table 1). Leaves produced more Chla, Chlb and Car as the NS concentration increased (Table 1). At $400 \mathrm{mM} \mathrm{NS}$, the leaf Chla and Chlb contents were $52 \%$ and $44 \%$ higher than those under non-saline soil conditions, respectively. However, the Chla, Chlb and Car of leaves responded differently to AS stress than to NS stress. The leaf chl content slightly increased as the AS concentration increased but significantly decreased at the AS concentration of $320 \mathrm{mM}$. Leaf Car were 
not affected by AS concentrations less than $320 \mathrm{mM}$; however, the Car increased at AS concentrations of $400 \mathrm{mM}$. The ratio of leaf Chla and Chlb increased as NS concentrations increased but decreased as AS concentrations increased.

Table 1. The mean contents of photosynthetic pigments (Chl - chlorophyll, Car carotenoids) [ $\mathrm{g} \mathrm{kg}^{-1}$ of fresh matter (FM)] in A. canescens seedlings under different NS and AS concentrations (0-400 $\mathrm{mM}$ ) after 20 days

\begin{tabular}{|c|c|c|c|c|c|}
\hline Treatment & $\begin{array}{c}\text { Salinity } \\
\text { concentration } \\
{[\mathrm{mM}]}\end{array}$ & $\begin{array}{c}\text { Chla } \\
{\left[\mathrm{mg} \mathrm{g}^{-1} \text { of dry matter }\right.} \\
\text { (DM)] }\end{array}$ & $\begin{array}{c}\text { Chlb } \\
{\left[\mathrm{mg} \mathrm{g}^{-1} \text { of DM] }\right.}\end{array}$ & Chla/Chlb & $\begin{array}{c}\text { Car } \\
{\left[\mathrm{mg} \mathrm{g}^{-1} \text { of DM }\right]}\end{array}$ \\
\hline Control & 0 & $1.42 \pm 0.07 \mathrm{c}$ & $0.43 \pm 0.01 \mathrm{~b}$ & $3.30 \pm 0.07 \mathrm{~b}$ & $0.35 \pm 0.01 \mathrm{~b}$ \\
\hline \multirow[t]{5}{*}{ NS } & 80 & $1.66 \pm 0.21 \mathrm{c}$ & $0.47 \pm 0.04 \mathrm{~b}$ & $3.53 \pm 0.12 b$ & $0.35 \pm 0.02 b$ \\
\hline & 160 & $1.85 \pm 0.09 \mathrm{~b}$ & $0.51 \pm 0.02 \mathrm{~b}$ & $3.62 \pm 0.06 \mathrm{a}$ & $0.38 \pm 0.06 \mathrm{a}$ \\
\hline & 240 & $1.90 \pm 0.14 b$ & $0.54 \pm 0.07 \mathrm{~b}$ & $3.51 \pm 0.11 \mathrm{~b}$ & $0.39 \pm 0.07 \mathrm{a}$ \\
\hline & 320 & $1.99 \pm 0.03 \mathrm{~b}$ & $0.56 \pm 0.06 \mathrm{a}$ & $3.55 \pm 0.08 \mathrm{~b}$ & $0.40 \pm 0.05 \mathrm{a}$ \\
\hline & 400 & $2.16 \pm 0.12 \mathrm{a}$ & $0.62 \pm 0.05 \mathrm{a}$ & $3.48 \pm 0.05 \mathrm{~b}$ & $0.41 \pm 0.01 \mathrm{a}$ \\
\hline Control & 0 & $1.42 \pm 0.07 \mathrm{~b}$ & $0.43 \pm 0.01 \mathrm{a}$ & $3.30 \pm 0.07 \mathrm{a}$ & $0.35 \pm 0.01 b$ \\
\hline \multirow[t]{5}{*}{ AS } & 80 & $1.49 \pm 0.05 \mathrm{~b}$ & $0.44 \pm 0.03 \mathrm{a}$ & $3.38 \pm 0.06 \mathrm{a}$ & $0.38 \pm 0.06 b$ \\
\hline & 160 & $1.52 \pm 0.06 \mathrm{a}$ & $0.45 \pm 0.01 \mathrm{a}$ & $3.37 \pm 0.11 \mathrm{a}$ & $0.38 \pm 0.07 \mathrm{~b}$ \\
\hline & 240 & $1.55 \pm 0.11 \mathrm{a}$ & $0.43 \pm 0.04 \mathrm{a}$ & $3.29 \pm 0.03 \mathrm{a}$ & $0.39 \pm 0.04 \mathrm{~b}$ \\
\hline & 320 & $1.29 \pm 0.13 \mathrm{c}$ & $0.38 \pm 0.07 \mathrm{~b}$ & $3.14 \pm 0.07 \mathrm{~b}$ & $0.37 \pm 0.01 \mathrm{~b}$ \\
\hline & 400 & $1.09 \pm 0.01 \mathrm{c}$ & $0.35 \pm 0.03 b$ & $2.86 \pm 0.08 \mathrm{c}$ & $0.47 \pm 0.05 \mathrm{a}$ \\
\hline
\end{tabular}

In each column, different letters indicate significant differences at $\mathrm{P}<0.05$ according to the Duncan test

\section{Effects of NS and AS on the $\mathrm{Na}^{+} / \mathrm{K}^{+}$of $A$. canescens seedlings}

The $\mathrm{Na}^{+}$and $\mathrm{K}^{+}$contents in $A$. canescens seedlings were differently influenced by AS than by NS. The $\mathrm{Na}^{+}$content in the leaves, stems and roots under AS conditions was higher than that under NS conditions, with the exception of the roots in which the AS concentrations of 320 and $400 \mathrm{mM}$ significantly inhibited root $\mathrm{Na}^{+}$absorption. At $400 \mathrm{mM} \mathrm{NS}$, the leaf, stem, and root $\mathrm{Na}^{+}$contents were approximately 17.25-, 14.89- and 3.86-fold higher than those of the control plants, respectively. Compared with NS stress, AS stress had a more profound effect on reducing the $\mathrm{K}^{+}$content in all plant organs.

Under NS conditions, the $\mathrm{K}^{+}$content in shoot tissue remained relatively constant as salinity increased, whereas the root $\mathrm{K}^{+}$content decreased as salinity increased. Similarly, the $\mathrm{K}^{+}$content significantly decreased in the leaves and the roots as the AS concentration increased (Fig. 3D-F). The $\mathrm{Na}^{+} / \mathrm{K}^{+}$ratios in the leaves and stems significantly increased as salinity increased, and a larger magnitude of increase occurred under NS conditions than under AS conditions. However, in the roots, the $\mathrm{Na}^{+} / \mathrm{K}^{+}$ratio peaked at $240 \mathrm{mM}$ under both NS and AS conditions, but the ratio decreased thereafter as the NS concentration increased (Fig. 3G-I).

\section{Discussion}

The RGR reflects the life-sustaining activities of plants and how they respond to stress (Wang et al., 2015). Our results showed that A. canescens can adjust to NS stress and AS stress. However, higher AS stress more strongly inhibits plant growth, which confirms our first hypothesis. We found that the growth rates peaked at moderate NS concentrations $(160 \mathrm{mM})$, and growth was maintained in non-saline environments at NS 
concentrations up to $400 \mathrm{mM}$. Similarly, Pan et al. (Pan et al., 2016) reported that $A$. canescens grew better under $100 \mathrm{mM} \mathrm{NaCl}$ conditions than under non-saline conditions; however, the salinity level at which the peak growth occurred was lower than the level we recorded in our experiments (100 $\mathrm{mM}$ vs. $160 \mathrm{mM})$. This finding might be attributed to the salt mixtures (i.e., $\mathrm{NaCl}$ and $\mathrm{Na}_{2} \mathrm{SO}_{4}$ ) that we used (Qiu et al., 2003). In contrast, growth was inhibited by external AS treatment (> $320 \mathrm{mM}$ ). Previous reports have also shown greater deleterious effects from alkaline stress than salt stress on other plant species, such as Aneurolepidium chinense, Chloris virgate, Suaeda corniculata, (Shi and Wang, 2005; Yang et al., 2007, 2008). The different influence of both kinds of stress on plant growth might be due to the different underlying mechanisms. Plant survival in AS soil relies not only on the ability to address ion toxicity and low water potential but also on the ability to tolerate high pH (Shi and Wang, 2005; Yang et al., 2007, 2008). Adjustments of the $\mathrm{pH}$ outside the roots may represent another key physiological mechanism of alkalinity resistance. Under high AS conditions, a high $\mathrm{pH}$ around the roots could disrupt the governing ion balance and nutrient supplies; this disruption could lead to the inhibition of transmembrane electrochemical potential gradients in the root cells, which would negatively impact photosynthetic parameters and growth. Moreover, our results also demonstrated that the different responses of the photosynthetic ability (Shabala et al., 2014), ion homeostasis and osmotic adjustment capacity of the $A$. canescens seedlings represented the mechanisms that drove the stronger growth inhibition under AS conditions than under NS conditions (Fig. 1).
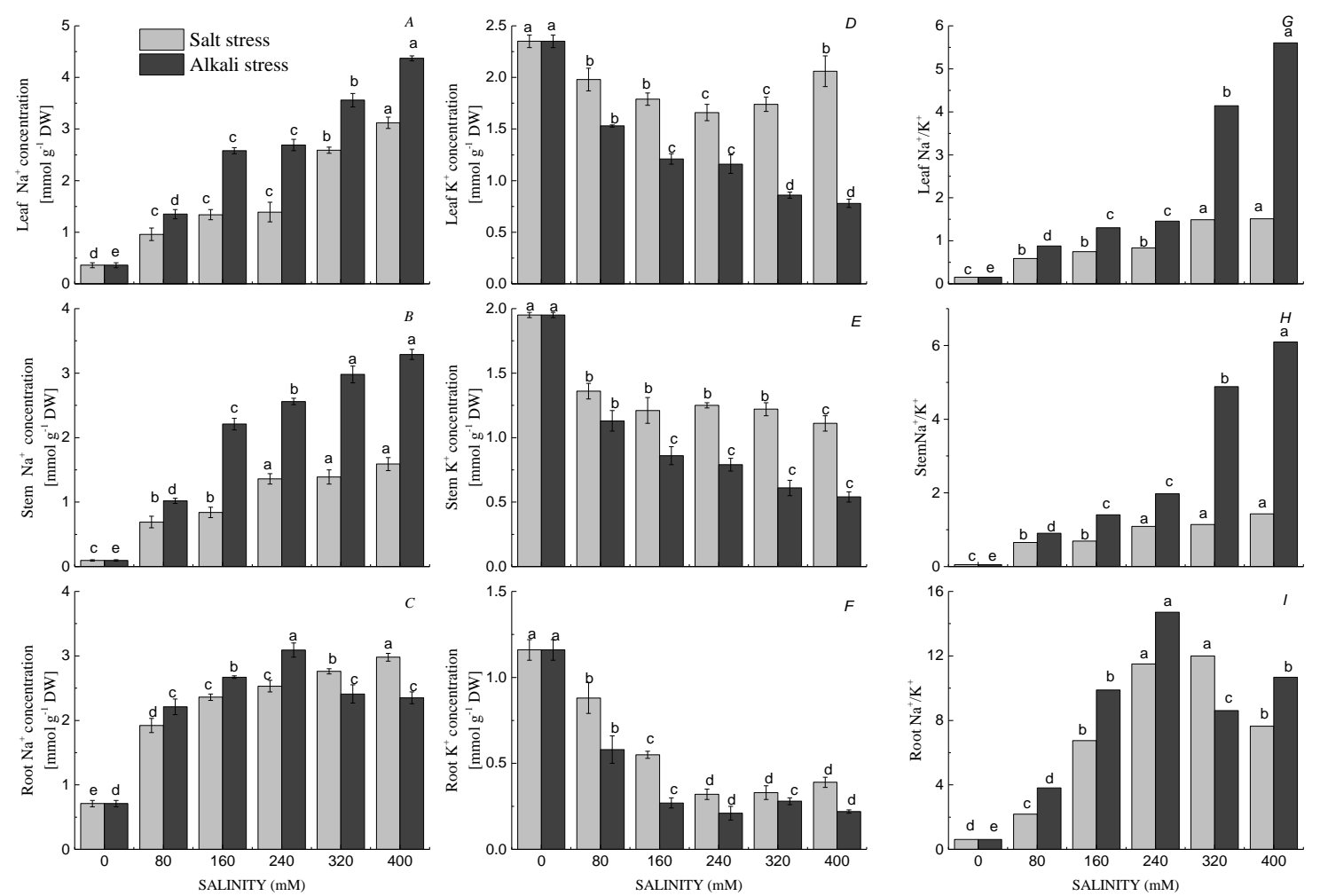

Figure 3. The mean $\mathrm{Na}^{+}$and $\mathrm{K}^{+}$contents and $\mathrm{Na}^{+} / \mathrm{K}^{+}$ratios in the leaves $(A, D, G)$, stems $(B, E$, $H)$ and roots $(C, F, I)$ of $A$. canescens seedlings under different $N S$ and $A S$ concentrations $(O-$ $400 \mathrm{mM}$ ) after 20 days. The error bars indicate $95 \%$ confidence intervals of the means.

Different letters in the same panel indicate significant differences at $P<0.05$ according to the Duncan test 
Plants must spend energy to adapt and exhibit resistance to stressful environments. The amount of energy spent directly depends on the photosynthetic ability (Wellburn and Lichtenthaler, 1984). The different growth rates of the A. canescens seedlings under the different treatments were basically the result of the Pn (Wang et al., 2004). In the present study, the Pn of the A. canescens seedlings significantly increased as both NS and AS concentrations increased, with the exception of that at 320 and $400 \mathrm{mM}$ AS (Tsutsumi et al., 2015). This finding indicated that the A. canescens seedlings strongly tolerated more than just salt and alkaline stress (Shi and Wang, 2015). However, the AS more strongly inhibited the Pn of the plants than did the NS, which is in line with our second hypothesis.

The responses of the Pn might be mediated by the photochemical process, resistance to gas exchange and the assimilatory system. Under moderate stress, A. canescens seedlings can increase cyclical electron transport (Bukhov and Carpentier, 2004) and photorespiration (Parida and Das, 2005) as mechanisms for protection against salinity. Furthermore, A. canescens seedlings can cope with excessive salt by decreasing their stomatal aperture to increase leaf WUE and carboxylation (Guy et al., 1980; Megdiche et al., 2008). Our results showed that the Gs first increased but then decreased as salinity increased. In contrast (Ma et al., 2012) reported that the Pn and Gs of Zygophyllum xanthoxylum were positively correlated. This correlation might be due to the different properties of $\mathrm{C}_{3}$ and $\mathrm{C}_{4}$ plants (Yang et al., 2017). Moderate $\mathrm{Na}^{+}$ concentrations may promote the $\mathrm{C}_{4}$ photosynthesis of $A$. canescens by facilitating the activity of photosystem II (PSII), converting pyruvate to phosphoenolpyruvate, as well as other biochemical processes in the photosynthetic pathway (Chaves et al., 2011; Kronzucker et al., 2013). In this study, we also found that the contents of Chla, Chlb and Car increased as the NS concentration increased. Under moderate stress, the $A$. canescens seedlings might accumulate photosynthetic pigments and metabolically regulate chl to adapt to NS or AS conditions. In addition, Car are not only photosynthetic pigments but also endogenous antioxidants. Apart from the photosynthetic function of Car, they can also prevent membrane lipid peroxidation (Yang et al., 2008). In contrast to the stimulating effects of the high levels of neutral salinity on the Pn, high concentrations of AS significantly reduced the Pn. This result might be due to the dual effects of stimulation and inhibition caused by the AS (Zhao et al., 2013). At AS concentrations of $320 \mathrm{mM}$, the inhibitory effects gradually strengthened as salinity increased and exceeded the stimulatory effects. High $\mathrm{pH}$ values may injure the photosynthetic system, possibly inhibiting the transmembrane electrochemical potential of PSII. The sudden increase in $\mathrm{Ci}$ also indicated a damaged photosynthetic system when the AS concentrations reached $320 \mathrm{mM}$ or greater (Yang et al., 2012). This $\mathrm{Ci}$ enhancement at AS concentrations of $320 \mathrm{mM}$ was probably caused by non-stomatal limitations in accordance with the Farquhar gas exchange model. For example, limiting Rubisco carboxylase activity and destroying chloroplast structure could explain the reductions in the Pn, causing Ci to increase (Bethke and Drew, 1992; James et al., 2006). Salinity induces a wide range of perturbations in terms of chl concentration and chloroplast structure (Abdelkader et al., 2007). In our study, the reduced chl content after an initial increase as the AS concentration increased might also indicate a stronger inhibitory impact of AS compared with NS on chl synthesis, and $\mathrm{Mg}^{2+}$ precipitation (Shi and Zhao, 1997). Furthermore, Chlb is an important component of the light-harvesting complex. The decrease in Chlb in our results might also impair the light-harvesting complex structure and function, consequently weakening the light 
absorption ability of the chloroplasts. To summarize the above results, the inhibition of A. canescens seedling growth under AS conditions might result from a decrease in the Pn, which might be due to non-stomatal limitations and lower chl concentrations caused by a high pH (Zhao et al., 2014).

In saline soil, $\mathrm{Na}^{+}$is considered a major toxic ion. Low $\mathrm{Na}^{+}$and high $\mathrm{K}^{+}$contents in plant cells are preconditions to the maintenance of enzymatic processes (Munns and Tester, 2008). Thus, maintaining a relatively constant intracellular $\mathrm{Na}^{+} / \mathrm{K}^{+}$homeostasis is crucial for plants to acclimate to salinity stress conditions (Zhu, 2003; Tang et al., 2014). In the present study, the $\mathrm{Na}^{+}$content was higher and the $\mathrm{K}^{+}$content was lower under AS conditions than under NS conditions (Volkov, 2015). The $\mathrm{Na}^{+} / \mathrm{K}^{+}$ratios increased along the salinity gradient. However, compared with the AS treatment, the NS treatment resulted in $\mathrm{Na}^{+} / \mathrm{K}^{+}$ratios that remained relatively constant as salinity increased. This finding confirmed our third hypothesis that AS more strongly influenced the $\mathrm{Na}^{+}$and $\mathrm{K}^{+}$contents in A. canescens seedlings than did NS (Zhang, 2013). The increased accumulation of $\mathrm{Na}^{+}$and decreased accumulation of $\mathrm{K}^{+}$represent mechanisms for adapting to salinity in Atriplex (Bajji et al., 1998; Bose et al., 2015; Ma et al., 2016). In the present study, the growth of $A$. canescens seedlings was positively affected by NS despite the increased $\mathrm{Na}^{+}$content, which might be attributed to two physiological processes. First, ion compartmentation enables plants to sequester a large quantity of excess $\mathrm{Na}^{+}$into epidermal bladder cells to avoid ion toxicity in organelles (Flowers and Colmer, 2008; Ding et al., 2010; Shabala, 2011, 2014). Second, A. canescens is capable of transporting $\mathrm{K}^{+}$instead of $\mathrm{Na}^{+}$from the roots to the stem or from the stem to the leaves to maintain a relatively constant cytosolic $\mathrm{Na}^{+} / \mathrm{K}^{+}$ratio in the shoots (Flowers and Colmer, 2008; Pan et al., 2016). In contrast, under AS conditions, the overaccumulation of $\mathrm{Na}^{+}$had adverse impact on the A. canescens seedlings. This finding might be related to reduced $\mathrm{Na}^{+}$sequestration within vacuoles and weakened control over $\mathrm{Na}^{+}$transport within plant tissues driven by high $\mathrm{pH}$ values (Chen et al., 2009). These phenomena can thus lead to a significant increase in $\mathrm{Na}^{+}$concentration and can disrupt ionic balance in tissues. Furthermore, AS can also neutralize the number of protons and weaken the establishment of $\mathrm{Na}^{+} / \mathrm{H}^{+}$antiporters in the plasma membrane, leading to the failure of $\mathrm{Na}^{+}$compartmentation (Munns and Tester, 2008; Pan et al., 2016). Our results further showed that the AS environment more strongly impeded the ability of plants to maintain $\mathrm{K}^{+}$uptake than did the NS environment. Similarly, excess $\mathrm{Na}^{+}$competes with $\mathrm{K}^{+}$uptake in many species. This phenomenon can inhibit $\mathrm{K}^{+}$ dependent metabolic process, such as the induction of the photosynthetic ATPase enzyme, and can inhibit the participation of $\mathrm{K}^{+}$during carbohydrate biosynthesis, consequently resulting in oxidative stress (Munns and Tester, 2008; Flowers et al., 2015; Volkov, 2015). We demonstrated that the disrupted $\mathrm{K}^{+}$and $\mathrm{Na}^{+}$homeostasis due to the high $\mathrm{pH}$ value is probably responsible for the inhibited growth and reduced $\mathrm{Pn}$ of A. canescens seedlings in AS environments.

\section{Conclusion}

Our results indicated that $A$. canescens seedlings can adapt to NS stress and AS stress though strengthening the photosynthetic ability and maintaining ionic homeostasis capacity. However, at higher concentrations (> $240 \mathrm{mM}$ ), alkali salinity more strongly inhibited plant performance than did neutral salinity, and the change was associated with a decrease in photosynthetic ability and damage to $\mathrm{Na}^{+} / \mathrm{K}^{+}$homeostasis under 
alkali salinity. A. canescens as an exotic tree species can used to achieve the ecological recovery and city afforestation for moderate salinization areas of northwest China. In this study, we compared the growth responses of Atriplex canescens to salt and alkaline stress under an optimal soil water condition. In the future, experiments may be conducted under different soil water conditions.

Acknowledgements. This study was funded by "Research and demonstration on saline-alkali land afforestation in Qaidam basin" (grant number 2014-NK-A4-4).

Conflict of interests. The authors declare that they have no conflict of interest.

Compliance with ethical standards. This article does not contain any studies with human participants or animals performed by any of the authors. Informed consent was obtained from all individual participants included in the study.

\section{REFERENCES}

[1] Abdelkader, A. F., Aronsson, H., Solymosi, K. et al. (2007): High salt stress induces swollen prothylakoids in dark grown wheat and alters both prolamellar body transformation and reformation after irradiation. - J Exp Bot 58: 2553-2564.

[2] Al-Turki, T. A., Omer, S., Ghafoor, A. (2000): A synopsis of the genus Atriplex L. (Chenopodiaceae) - Feddes Repert 111: 261-293.

[3] Araùjo, Desilveira, S. A. M., Silveira, Almeida, J. A. G. et al. (2006): Salinity tolerance of halophyte Atriplex nummularia L. grown under increasing $\mathrm{NaCl}$ levels. - Revista Brasileira de Engenharia Agricola e Ambiental. -Agriambi 10: 65-66.

[4] Ayala, F., O'Leary, J. W., Schumaker, K. S. (1996): Increased vacuolar and plasma membrane $\mathrm{H}^{+}$-ATPase activities in Salicornia bigelovii Torr. in response to $\mathrm{NaCl}$. Journal of Experimental Botany 47(1): 25-32.

[5] Bajji, M., Kinet, J. M., Lutts, S. (1998): Salt stress effects on roots and leaves of Atriplex halimus L. and their corresponding callus cultures. - Plant 137: 131.

[6] Bao, A. K., Du, B. Q., Touil, L. et al. (2016): Co-expression of tonoplast Cation/ $\mathrm{H}^{+}$ antiporter (NHX) and $\mathrm{H}^{+}$-pyro phosphatase $\left(\mathrm{H}^{+}\right.$-PPase) from xerophyte Zygophyllum xanthoxylum improves alfalfa plant growth under salinity, drought, and field conditions. Plant Biotechnol. J. 14: 964-975.

[7] Ben Hassine, A., Ghanem, M. E., Bouzid, S., Lutts, S. (2008): An inland and a coastal population of the Mediterranean xero-halophyte species Atriplex halimus L. differ in their ability to accumulate proline and glycinebetaine in response to salinity and water stress. J. Exp. Bot 59: 1315-1326.

[8] Benzarti, M., Ben Rejeb, Debez, A. et al. (2013): Environmental and Economical Opportunities for the Valorisation of the Genus Atriplex: New Insights. - In: Hakeem, K., Ahmad, P., Ozturk, M. (eds.) Crop Improvement. - Springer, New York, pp. 441-457.

[9] Benzarti, M., Rejeb, K. B., Debez, A. et al. (2012): Photosynthetic activity and leaf anti oxidative responses of Atriplexportulacoides - subjected to extreme salinity. - Acta Physiologiae Plantarum 34: 1679-1688.

[10] Benzarti, M., Rejeb, K. B., Messedi, D. et al. (2014): Effect of high salinity on Atriplex portulacoides: growth, leaf water relations and solute accumulation in relation with osmotic adjustment. - South African Journal of Botany 95: 70-77.

[11] Bethke, P. C., Drew, M. C. (1992): Stomatal and non-stomatal components to inhibition of photosynthesis in leaves of Capsicum annuum during progressive exposure to $\mathrm{NaCl}$ salinity. - Plant Physiol 99: 219-226. 
[12] Bose, J., Rodrigo-Moreno, A. Lai et al. (2015): Rapid regulation of the plasma membrane $\mathrm{H}^{+}$-ATPase activity is essential to salinity tolerance in two halophyte species, Atriplex lentiformis and Chenopodium quinoa. - Ann. Bot 115: 48181.

[13] Bouchenak, F., Henri, P., Bebrebiha, F. Z. et al. (2012): Differential responses to salinity of two Atriplex halimus populations in relation to organic solutes and antioxidant systems involving thiol reductases. - J. Plant Physiol 169: 1445-1453.

[14] Bukhov, N., Carpentier, R. (2004): Alternative photosystem I-driven electron transport routes: mechanisms and functions. - Photosynthesis Research 82: 17-33.

[15] Campbell, S. A., Nishio, J. N. (2000): Iron deficiency studies of sugar beet using an improved sodium bicarbonate-buffered hydroponics growth system. - J. Plant Nutr 23: 741-757.

[16] Chaves, M. M., Costa, J. M., Saibo, N. M. (2011): Recent advances in photosynthesis under drought and salinity. - Adv. Bot. Res. 57: 49-104.

[17] Chen, W., Cui, P., Sun, H. et al. (2009): Comparative effects of salt and alkaline stresses on organic acid accumulation and ionic balance of sea buckthorn (Hippophaer hamnoides L). - Industrial Crops \& Products 30(3): 351-358.

[18] Debez, A., Koyro, H. W., Grignon, C. et al. (2008): Relationship between the photosynthetic activity and the performance of Cakile maritima after long-term salt treatment. - Physiol Plant 133(2): 373-385.

[19] Ding, F., Yang, J. C., Yuan, F. et al. (2010): Progress in mechanism of salt excretion in recreto halopytes. - Front. Biol 5(2): 164-170.

[20] Elshma, S. (1996): Comparative effect of sodium carbonate, sodium sulphate, and sodium chloride on the growth and related metabolic activities of pea plants. - J. Plant Nutr 19: 717-728.

[21] Flowers, T. J. (2004): Improving crop salt tolerance. - J. Exp. Bot 55: 307-319.

[22] Flowers, T. J., Colmer, T. D. (2008): Salinity tolerance in halophytes. - New Phytol 179: 945-963.

[23] Flowers, T. J., Galal, H. K., Bromham, L. (2010): Evolution of halophytes: multiple origins of salt tolerance in land plants. - Funct. Plant Biol 37: 604-612.

[24] Flowers, T. J., Munns, R. Colmer, T. D. (2015): Sodium chloride toxicity and the cellular basis of $\mathrm{s}$ alt tolerance in halophytes. - Ann. Bot 115: 419-431.

[25] Ge, Y., Li, J. D. (1990): A preliminary study on the effects of halophytes on salt accumulation and desalination in the soil of Songnen Plain, northeast China. - Acta Pratacult Sin 70-76.

[26] Ghoulam, C., Foursy, A., Fares, K. (2002): Effects of salt stress on growth, inorganic ions and proline accumulation in relation to osmotic adjustment in five sugar beet cultivars. Environ Exp Bot 47: 39-50.

[27] Glenn, E. P., Brown, J. J. (1999): Effects of soil salt levels on the growth and water use efficiency of Atriplex canescens (Chenopodiaceae) varieties in drying soil. - Am. J. Bot 85: 10-16.

[28] Glenn, E. P., Pfister, R., Briwn, J. J. et al. (1996): Na and K accumulation and salt tolerance of Atriplex canescens (Chenopodiaceae) genotypes. - Am. J. Bot 83: 997-1005.

[29] Glenn, E. P., Olsen, M., Frye, R. et al. (2010): How much sodium accumulation is necessary for salt tolerance in subspecies of the halophyte Atriplex canescens. - Plant Cell Environ 17: 711-719.

[30] Gong, B., Zhang, C. J., Li, X. et al. (2014): Identification of $\mathrm{NaCl}$ and $\mathrm{NaHCO}_{3}$ stress responsive proteins in tomato roots using iTRAQ-based analysis. - Biochem. Biophys. Res. Commun 446: 417-422.

[31] Guy, R. D., Reid, D. M., Krouse, H. R. (1980): Shifts in carbon isotope ratios of two C3, halophytes under natural land artificial conditions. - Oecologia 44: 241-247. 
[32] Hamdia, M., Shaddad, H. M. A., Ellogamad, A. (1996): Comparative effect of sodium carbonate, sodium sulphate, and sodium chloride on the growth and related metabolic activities of pea plants. - J. Plant Nutr 19(5): 717-728.

[33] Hao, G. Y., Lucero, M. E., Sanderson, S. C. et al. (2013): Polyploidy enhances the occupation of heterogeneous environments through hydraulic related trade-offs in Atriplex canescens (Chenopodiaceae). - New Phytol 197: 970-978.

[34] Hassine, A. B., Lutts, S. (2010): Differential responses of saltbush Atriplex halimus L. exposed to salinity and water stress in relation to senescing hormones abscisic acid and ethylene. - J. of Plant Physiol 167: 1448-1456.

[35] Hassine, A. B., Ghanem, Bouzid, S. et al. (2008): An inland and a coastal population of the Mediterranean xero-halophyte species Atriplex halimus L. differ in their ability to accumulate proline and glycine betaine in response to salinity and water stress. - J. Exp. Bot 59: 1315 .

[36] James, R. A., Munns, R., Caemmerer, S. V. et al. (2016): Photosynthetic capacity is related to the cellular and subcellular partitioning of $\mathrm{Na}^{+}, \mathrm{K}^{+}$and $\mathrm{Cl}^{-}$in salt-affected barley and durum wheat. - Plant Cell Environ 29: 2185-2197.

[37] Jamil, F., Arshad, R., Ali, M. A. (2018): Design, fabrication and evaluation of rotary hotair dryer for the value addition of fruit waste. - Earth Sciences Pakistan 2(2): 07-11.

[38] Kalaji, H. M., Jajoo, A. et al. (2016): Chlorophyll a fluorescence as a tool to monitor physiological status of plants under abiotic stress conditions. - Acta Physiol. Plant 38: 102. https://doi.org/10.1007/s11738-016-2113-y.

[39] Kawanabe, S., Zhu, T. C. (1991): Degeneration and conservation of Aneurolepidium chinense grassland in Northern China. - J. Jap. Grassland Soc 37: 91-99.

[40] Kingsbury, R. W., Epstein, E. et al. (1984): Physiological responses to salinity in selected lines of wheat. - Plant Physiol 74: 417-423.

[41] Kong, D. S. (2013): Morphological characteristics and eco-physiological adaptability of Atriplex canescens: a review. - Chin. J. Ecol 32: 210-216.

[42] Kronzucker, H. J., Coskun, D., Schulze, L. M. et al. (2013): Sodium as nutrient and toxicant. - Plant Soil 369: 1-23.

[43] Kumar, R. (2018): Comparison of instruction scheduling and register allocation for MIPS and HPL -PD architecture for exploitation of instruction level parallelism. - Engineering Heritage Journal 2(2): 04-08.

[44] Li, P. H., Zhang, H. Wang, B. S. (2003): Ionic homeostasis of plant under salt stress. Acta Bot Boreal-Occident Sin 23: 1810.

[45] Lichtenthaler, H. K. (1987): Chlorophylls and carotenoids: pigments of photosynthetic biomembranes. - Methods in Enzymology 148: 350-382.

[46] Ma, Q., Yue, L. J., Zhang, J. L. et al. (2012): Sodium chloride improves photosynthesis and water status in the succulent xerophyte Zygophyllumx anthoxylum. - Tree Physiol 32: 4-13.

[47] Ma, Q., Bao, A. K., Chai, W. W. et al. (2016): Transcriptomic analysis of the succulent xerophyte Zygophyllum xanthoxylumin response to salt treatment and osmotic stress. Plant Soil 402(1-2): 343-361.

[48] Madhav, S., Ahamad, A., Kumar, A., Kushawaha, J., Singh, P., Mishra, P. K. (2018): Geochemical assessment of groundwater quality for its suitability for drinking and irrigation purpose in rural areas of Sant Ravidas Nagar (Bhadohi), Uttar Pradesh. Geology, Ecology, and Landscapes 2(2): 127-136.

[49] Marttnez, J. P., Lutts, S., Schanck, A. et al. (2004): Is osmotic adjustment required for water-stress resistance in the Mediterraneanshrub Atriplex halimus L? - Plant Physiol 161: 10411.

[50] Megdiche, W., Hessini, K., Gharbi, F. et al. (2008): Photosynthesis and photosystem 2 efficiency of two salt-adapted halophytic seashore Cakilemaritima ecotypes. - Photosynthetica 46: 410-419. 
[51] Munns, R., Tester, M. (2008): Mechanisms of salinity tolerance. Annu. Rev. - Plant Biol 59: 651-681.

[52] Nemat-Alla, M. M., Khedr, A. H. A., Serag, M. M. et al. (2011): Physiological aspects of tolerance in Atriplexhalimus L. to $\mathrm{NaCl}$ and drought. - Acta Physiol. Plant 33: 547-557.

[53] Niu, S. Q., Li, H. R., Paré, P. W. et al. (2016): Induced growth promotion and higher salt tolerance in the halophyte grass Puccinellia tenuiflora by beneficial rhizobacteria. - Plant \& Soil 407(1-2): 1-14.

[54] Nkwuda, N. G., Theophine, M. A., Okogwu, O. I. (2019): Impacts of rock mineralization and poor sanitary system on borehole waters quality and the health implications. - Earth Sciences Pakistan 3(1): 10-13.

[55] Nwankwo, C., Nwankwoala, H. O. (2018): Gully erosion susceptibility mapping in Ikwuano local government area of Abia State using GIS techniques. - Earth Sciences Malaysia 2(1): 08-15.

[56] Ogunyele, A. C., Obaje, S. O., Akingboye, A. S. (2018): Lithostructural relationships and petrogenetic affinities of the basement complex rocks around Okpella, Southwestern Nigeria. - Earth Sciences Malaysia 2(1): 29-36.

[57] Ortiz-Dorda, J., Martinez-Mora, C., Correal, E. et al. (2005): Genetic structure of Atriplex halimus populations in the Mediterranean Basin. - Ann Bot 95: 827-834.

[58] Pan, Y. Q., Guo, H., Wang, S. M. et al. (2016): The photosynthesis, $\mathrm{Na}^{+} / \mathrm{K}^{+}$homeostasis and osmotic adjustment of Atriplex canescensin response to salinity. - Frontiers in Plant Science 7(848).

[59] Parida, A. K., Das, A. B. (2005): Salt tolerance and salinity effects on plants: a review. Ecotoxicology and Environmental Safety 60: 324-349.

[60] Peterson, J. L., Ueckert, D. N., Potter, R. L. et al. (1987): Ecotypic variation in selected fourwing saltbush populations in western Texas. - J. Range Manage. Arch 40: 361-366.

[61] Qiu, N., Lu, Q., Lu, C. (2003): Photosynthesis, photosystem II efficiency and the xanthophyll cycle in the salt-adapted halophyte Atriplex centralasiatica. - New Phytologist 159: 479-486.

[62] Raj, N. J., Prabhakaran, A. (2018): Lineaments of Kodaikanal-Palani massif, Southern Granulitic Terrain of Tamil Nadu, India: a study using SRTM DEM and LANDSAT satellite's OLI sensor's FCC. - Geology, Ecology, and Landscapes 2(3): 188-202.

[63] Rajendran, Y., Mohsin, R. (2018): Emission due to motor gasoline fuel in reciprocating lycoming O -320 engine in comparison to aviation gasoline fuel. - Environment \& Ecosystem Science 2(2): 20-24.

[64] Redondo-Gómez, S., Figueroa, M. E. (2007): Growth and photosynthetic responses to salinity of the salt-marsh shrub Atriplex portulacoides. - Annals of Botany 100: 55-63.

[65] Roosta, H. R., Karimi, H. R. (2002): Effects of alkali-stress on ungrafted and grafted cucumber plants using two types of local squash as rootstock. - J. Plant Nutr 35: 18431852.

[66] Sa, R. L., Liu, J. H., Liu, W. et al. (2004): Cation-responsive mechanisms of Oats to alkaline stress. - Acta Agron. Sin 40: 362-368.

[67] Sergey, S. (2013): Learning from halophytes: physiological basis and strategies to improve abiotic stress tolerance in crops. - Ann. Bot 112: 1209-1221.

[68] Shabala, S., Mackay, A. (2011): Ion transport in halophytes. - Adv. Bot. Res 57: 151199.

[69] Shabala, S., Bose, J., Hedtich, R. (2014): Salt bladders: do they matter? - Trends Plant Sci 19: 687-691.

[70] Shi, D. C., Sheng, Y. (2005): Effect of various salt-alkaline mixed stress conditions on sunflower seedlings and analysis of their stress factors. - Environ Exp Bot 54: 8-21.

[71] Shi, D. C., Wang, D. (2005): Effects of various salt-alkali mixed stresses on Aneurolepidium chinense (Trin.) Kitag. - Plant Soil 271: 15-26. 
[72] Shi, D. C., Yin, L. J. (1993): Difference between salt $(\mathrm{NaCl})$ and alkaline $\left(\mathrm{Na}_{2} \mathrm{CO}_{3}\right)$ stresses on Puccinellia tenuiflora (Griseb.) Scribn. et Merr. plants. - Acta Bot. Sin. 35: 144-149.

[73] Shi, D. C., Zhao, K. F. (1997): Effects of $\mathrm{NaCl}$ and $\mathrm{Na}_{2} \mathrm{CO}_{3}$ on growth of Puccinelliatenuiflora and on present state of mineral elements in nutrient solution. Actapratacu. Sin 6: 51-61.

[74] Sufiyan, I., Zakariya, R., Yaacob, R. (2018): Delineation of flood risk zones and 3D modeling in Terengganu River catchment using GIS and SWAT. - Environment \& Ecosystem Science 2(2): 01-05.

[75] Tang, X. L., Mu, X., Wang, H. et al. (2014): Global plant-responding mechanisms to salt stress: physiological and molecular level sand implications in biotechnology. - Crit. Rev. Biotechnol 35: 425-437.

[76] Tanji, K, K. (2002): Salinity in the Soil Environment. - In: Läuchli A., Lüttge U. (eds.) Salinity: Environment - Plants - Molecules. Springer, Dordrecht, pp. 21-51.

[77] Tianlei, W. (2019): Nonlinear control strategies and planning for underactuated overhead cranes. - Engineering Heritage Journal 3(1): 09-12.

[78] Tsutsumi, K., Yamada, N. et al. (2015): Differential accumulation of glycine betaine and choline monooxygenase inbladder hairs and lamina leaves of Atriplexgmelini under high salinity. - Plant Physiol 176: 101-107.

[79] Volkov, V. (2015): Salinity tolerance in plants. Quantitative approach to ion transport starting from halophytes and stepping to genetic and proteinengineering for manipulating ion fluxes. - Front. Plant Sci 6: 873.

[80] Wang, P., Guo, Q., Wang, Q., Zhou, X. R. et al. (2015): PtAKT1 maintains selective absorption capacity for $\mathrm{K}^{+}$over $\mathrm{Na}^{+}$in halophyte Puccinellia tenuiflora under salt stress. Acta Physiol. Plant 37: 100.

[81] Wang, S., Wan, C., Wang, Y. et al. (2004): The characteristics of $\mathrm{Na}^{+}, \mathrm{K}^{+}$and free proline distribution in several drought-resistant plants of the Alxa Desert, China. Journal of Arid Environments 56: 525-539.

[82] Wellburn, A. R., Lichtenthaler, H. (1984): Formulae and Program to Determine Total Carotenoids and Chlorophylls A and B of Leaf Extracts in Different Solvents. - In: Sybesma C. (ed.) Advances in Photosynthesis Research. Advances in Agricultural Biotechnology. Vol 2. Springer, Dordrecht, pp. 9-12.

[83] Yan, K., Shao, H. (2013): Physiological adaptive mechanisms of plants grown in saline soil and implications for sustainable saline agriculture in coastal zone. - Acta Physiol. Plant 35: 2867-2878.

[84] Yang, C., Chong, J., Li, C. et al. (2007): Osmotic adjustment and ion balance traits of an alkali resistant halophyte Kochia sieversiana, during adaptation to salt and alkali conditions. - Plant and Soil 294: 263-276.

[85] Yang, C. W. (2009): Comparative effects of salt-stress and alkali-stress on the growth, photosynthesis, solute accumulation, and ion balance of barley plants. - Photosynthetica 47: 79-86.

[86] Yang, C. W., Chong, J., Li, C. et al. (2007): Osmotic adjustment and ion balance traits of an alkali resistant halophyte Kochia sieversiana during adaptation to salt and alkali conditions. - Plant Soil 294: 263-276.

[87] Yang, C. W., Jianaer, A., Li, C. Y. et al. (2008): Comparison of the effects of salt-stress and alkali-stress on photosynthesis and energy storage of an alkali-resistant halophyte Chloris virgate. - Photosynthetica 46: 273-278.

[88] Yang, C. W., Zhao, N., Xu, C. M. et al. (2012): Regulation of ion homeostasis in rice subjected to salt and alkaline stresses. - Aust. J. Crop Sci 6: 724-731.

[89] Zhang, J. F., Song, Y. M., Xing, S. J. et al. (2002): Saline soil amelioration and forestation techniques. - Journal of Northeast Forestry University 30(6): 124-129. 
[90] Zhang, W. P., Yang, J. Z., Fang, Y. L., Chen, H. Y., Mao, Y. H., Kumar, M. (2017): Analytical fuzzy approach to biological data analysis, - Saudi Journal of Biological Sciences 24(3): 563-573.

[91] Zhang, X., Wei, L., Wang, Z. et al. (2013): Physiological and molecular features of Puccinellia tenuiflora tolerating salt and alkaline-salt stress. - J. Integr. Plant Biol 55: 262-276.

[92] Zhao, Y. Y., Lu, Z., He, L. (2014): Effects of saline-alkaline stress on seed germination and seedling growth of Sorghum bicolor (L.) Moench. - Appl. Biochem. Biotech 173: $1680-1691$.

[93] Zhu, J. K. (2003): Regulation of ion homeostasis under salt stress. - Plant Biol 6: 441445.

[94] Zhu, J. K. (2014): Plant salt tolerance. - Trends Plant Sci 6: 66-71. 